\title{
Pathogenesis of Shiga Toxin-Associated Hemolytic Uremic Syndrome
}

\author{
FRANÇOIS PROULX, ERNEST G. SEIDMAN, AND DIANA KARPMAN \\ Department of Pediatrics, Sainte-Justine Hospital, University of Montreal, 3175 Chemin Côte \\ Sainte-Catherine, Montreal, Canada, H3T-1C5 [F.P., E.G.S.]; and the Department of Pediatrics, Lund \\ University, 22185 Lund, Sweden [D.K.]
}

\begin{abstract}
The aim of this review is to examine recent advances in experimental and clinical research relevant to the pathogenesis of diarrhea-associated hemolytic uremic syndrome with special reference to histopathologic findings, virulence factors of Shiga toxin-producing Escherichia coli, the host response, and the prothrombotic state. Despite significant advances during the past decade, the exact mechanism by which Shiga toxin-producing $E$. coli leads to hemolytic uremic syndrome remains unclear. Factors such as Shiga toxin, lipopolysaccharide, the adhesins intimin and E. coli-secreted proteins A, B, and D, the 60-MD plasmid, and enterohemolysin likely contribute to the pathogenesis. Data on the inflammatory response of the host, including leukocytes and inflammatory mediators, are updated. The pathogenesis of the prothrombotic state leading to thrombocytopenia secondary to endothelial cell damage and platelet activation is also discussed. A hypothetical sequence of events from ingestion of the
\end{abstract}

ABSTRACT

bacteria to the development of full-blown hemolytic uremic syndrome is proposed. (Pediatr Res 50: 163-171, 2001)
HUS, hemolytic uremic syndrome diarrhea
E. coli
Esps, $\boldsymbol{E}$. coli-secreted proteins
LPS, lipopolysaccharide
Gb3, globotriaosylceramide
TNF- $\alpha$, tumor necrosis factor- $\alpha$

STEC, Shiga toxin-producing $E$. coli Stx, Shiga toxin

$\mathbf{D}^{+}$HUS, diarrhea-associated hemolytic uremic syndrome

D $^{-}$HUS, hemolytic uremic syndrome not associated with

EHEC, enterohemorrhagic E. coli EPEC, enteropathogenic
Nonimmune hemolytic anemia, thrombocytopenia, and acute renal failure are cardinal features of HUS (1). CNS manifestations may also be noted (2). HUS most frequently occurs among children younger than 5 years of age, after a diarrheal prodrome $\left(\mathrm{D}^{+}\right.$HUS) typically characterized by bloody diarrhea, termed hemorrhagic colitis. This form of HUS may also occur in adults, more often among the elderly. In North America and Western Europe, Stx (also called verotoxin) -producing $E$. coli, most frequently involving the serotype $\mathrm{O} 157: \mathrm{H7}$, is the leading cause of $\mathrm{D}^{+}$HUS (3-5). This review will address current knowledge about the pathogenesis of HUS caused by STEC.

Received October 27, 2000; accepted March 19, 2001.

Correspondence and reprint requests: François Proulx, M.D., Department of Pediatrics, Sainte-Justine Hospital, 3175 Chemin Côte Sainte-Catherine, Montreal, Quebec, Canada H3T-1C5; e-mail: fproulx_01@yahoo.ca

F.P. is supported by grants from le club de services Sainte-Justine Hospital, Telethon of Stars. E.G.S. is supported by a research chair from the Canadian Institutes of Health Research and the Crohns and Colitis foundation of Canada. D.K. is supported by grants from The Swedish Research Council (K2001-06X-14008-01A), the Ronald McDonald Pediatric Fund, and the Swedish Renal Foundation.

\section{HISTOPATHOLOGY OF $\mathrm{D}^{+}$HUS}

The histopathologic features observed in HUS have been termed thrombotic microangiopathy, a term that also encompasses other conditions such as HUS not associated with a diarrheal prodrome ( $\mathrm{D}^{-}$HUS) and thrombotic thrombocytopenic purpura (6). Endothelial cell damage is the hallmark of thrombotic microangiopathy found in $\mathrm{D}^{+}$HUS. Fibrin thrombi are predominantly formed within small vessels, followed by ischemic damage. Glomerular endothelial cell swelling, thrombotic occlusion of capillary lumens, tubular epithelial cell damage, mesangial expansion, and mesangiolysis have been observed (6). In the most severe cases, extensive cortical necrosis ensues. Inflammatory cell infiltrates within the kidneys are predominantly composed of neutrophils and macrophages $(7,8)$. Moreover, apoptosis of renal cortical glomerular and tubular cells is well documented $(9,10)$. Lesions of the gastrointestinal tract usually consist of small vessel angiopathy in the mucosa and submucosa of the small and large intestine with hemorrhage, necrosis, and sloughing of cells into the lumen (11). Thrombotic microangiopathy may also be noted in other organs such as the CNS (2). The histopathologic findings in $\mathrm{D}^{-}$HUS and thrombotic thrombocytopenic purpura are 
different from those in $\mathrm{D}^{+}$HUS. In $\mathrm{D}^{-}$HUS, the lesions are arteriolar, with thrombi and intimal proliferation. In $\mathrm{D}^{+} \mathrm{HUS}$ the lesions are glomerular with occlusion of capillary lumens. There is mesangial expansion, and, in severe cases, cortical necrosis is noted $(12,13)$. Moreover, fibrin thrombi are characteristic of $\mathrm{D}^{+}$HUS, whereas platelets and von Willebrand factor constitute those seen in thrombotic thrombocytopenic purpura (14).

\section{STEC VIRULENCE FACTORS}

Strains of STEC that can cause hemorrhagic colitis and HUS have been termed EHEC. These include E. coli O157:H7 and many other serotypes. Food- and water-borne transmission are the most important means of infection (15-18), although person-to-person contamination has been recognized (19). Except for two case reports $(20,21)$, there is no evidence for bacteremia in human disease. It is therefore assumed that systemic spread of bacterial products may lead to damage of target organs. EHEC strains express Stxs, LPS, adhesins such as intimin and Esps A, B, and D, enterohemolysin, a serine protease EspP, and a heat-stable enterotoxin (22-27).

Shiga toxin. Stx has been implicated in the pathogenesis of HUS because cases have been associated with Stx-producing bacteria such as E. coli (22), Shigella (28), and Citrobacter freundii (29). On the other hand, EPEC, which possess many virulence factors found in EHEC, but not Stx, have never been associated with HUS.

Human isolates of STEC may express Stx1 or Stx2 encoded on a bacteriophage. The holotoxin includes one A subunit and five B subunits. The B subunit binds to glycosphingolipid receptors, predominantly Gb3 $(30,31)$. The A subunit has $N$-glycosidase activity, which leads to cell death by inhibition of protein synthesis at the level of 28S ribosomal RNA (32). Except for one amino acid substitution in the former, Stx1 from E. coli is virtually identical to the toxin produced by Shigella dysenteriae and approximately $60 \%$ homologous to Stx 2 . There are different pathways of translocation for Stx 1 and Stx2 through the intestinal epithelium (33). Several observations suggest that Stx2 may be more virulent in human disease than Stx1. Clinical isolates of E. coli $\mathrm{O} 157: \mathrm{H} 7$ from patients with hemorrhagic colitis or HUS produced Stx2 more frequently than Stx1 (34-37). Moreover, an i.v. infusion of Stx2 in mice was found to be 400 times more potent than Stx1 (38). Similarly, human intestinal endothelial cells and renal glomerular endothelial cells are more sensitive to the cytotoxic effects of Stx2 than Stx1 $(39,40)$.

Stx-induced disease in animals. HUS preceded by hemorrhagic colitis has been described in several types of dogs as a naturally occurring disease (41). Greyhounds are known to develop a disease termed cutaneous and renal glomerular vasculopathy (Alabama rot), leading to an HUS-like condition $(42,43)$. STEC have been isolated in some cases of this canine disease (44). Edema disease in pigs causing vascular damage to the brain stem has been associated with Stx2e producing STEC (45). Swollen head syndrome is an acute respiratory disorder in poultry associated with STEC producing Stx2y (46). Although STEC cause disease in animals, no animal model has suc- ceeded in reproducing all aspects of human disease after oral ingestion of the offending bacteria. Herein we will discuss several animal models that highlight aspects of human HUS. A more detailed description of animal models can be found in a current review (47).

In vivo studies with Stx. In vivo studies have indicated that STEC strains are pathogenic (48-54). The strains cause gastrointestinal, neurologic, or systemic symptoms and death in gnotobiotic piglets $(50,51,55)$, rabbits (49), and mice (48, $52-54,56)$. Inoculated animals developed histopathologic lesions such as inflammatory colitis (50), brain endothelial cell necrosis and neuronal impairment $(52,55)$, acute tubular necrosis, and mesangial expansion in the kidneys $(48,54,56)$. In addition, mice inoculated intragastrically with $E$. coli $\mathrm{O} 157: \mathrm{H} 7$ had fragmented erythrocytes in the circulation (48), an aspect of disease that resembles human HUS. Comparison of toxinpositive with toxin-negative strains has shown that the former induces vascular colonic damage in a Shigella primate model (57) and glomerular mesangial changes, renal cortical apoptosis, and severe neurologic symptoms in an E. coli $\mathrm{O} 157: \mathrm{H} 7$ mouse model, changes not seen in animals infected with a toxin-negative strain $(9,48)$. The presence of $\mathrm{Gb} 3$ or galabiosyl ceramide receptors on cells has been found to determine the localization of tissue damage in rabbits, mice, and humans (38, $58,59)$. Species-specific differences in the distribution of Gb3 receptors have been proposed to determine the localization of pathologic lesions in different animal models. The kidney and the CNS are richly endowed with Gb3, likely explaining the tissue tropism of Stx $(60,61)$.

In vivo experiments with purified Stx have reproduced aspects of HUS, with damage to the intestine, kidney, and CNS in rabbits and mice (62-64). Baboons infused with Stx1 develop renal failure, anemia, thrombocytopenia, and injury to intestinal epithelium, glomerular endothelial cells, and renal proximal tubular cells (65). In this experimental model, thrombi were noted in renal glomerular and peritubular capillaries, resembling the pathologic alterations seen in human HUS.

In vitro studies with Stx. Stx is cytotoxic for human endothelial cells $(40,66-71)$ and may also induce apoptosis (72). Prestimulation of endothelial cells with TNF- $\alpha$, IL-1 $\beta$, or sodium butyrate resulted in an increase in Gb3 receptors, rendering the cells more susceptible to the cytotoxic effect of Stx (70, 73-75). Stx may directly lead to endothelial cell activation with perturbed expression of endothelial-derived vasomediators (76). Both Stx 1 and Stx2 directly activate bovine endothelial cells by increasing the production of preproendothelin mRNA transcript levels, without modifying that of nitric oxide (76). This effect was not observed with the receptor-binding B subunit, which lacks the $N$-glycosidase. In contrast, purified Stx was found to increase nitric oxide release from murine macrophages (77).

In addition to endothelial cells, Stx has been shown to have a cytotoxic effect on various other cells, including renal glomerular and tubular epithelial cells $(78,79)$. Cells lacking the toxin receptor were found to be resistant to the toxic effect (80). Stx can induce apoptosis in renal tubular epithelial cells $(9,81)$ as well as in Burkitt lymphoma cells (82), intestinal epithelial 
cells $(63,83)$, pulmonary epithelium-derived cells (84), and Vero cells (85). Cell death was not only induced by the holotoxin but also by high doses of the B subunit, indicating that this effect may be independent of the effect on protein synthesis (82). Apoptosis was demonstrated in kidneys from patients with HUS and in mice inoculated with Stx-positive strains, but not Stx-negative strains (9). Taken together with the finding that Stx is capable of inducing apoptosis in renal tubular epithelial cells, these studies indicate that Stx-induced apoptosis may contribute to the renal injury during HUS. Apoptosis has been shown to be a causal mechanism in the pathogenesis of renal tubular injury and glomerular sclerosis (86-88).

Several studies have addressed the pathway by which Stx translocates from the intestinal lumen into the circulation. Stx 1 translocation through intestinal epithelial cells occurs via a transcellular route, whereas that of Stx 2 occurs through a paracellular pathway $(33,89)$. The toxin may also bind to intestinal endothelial cells (39) and, by damaging both epithelial and endothelial cells, induce hemorrhagic colitis and gain access to the bloodstream.

Lipopolysaccharide. Endotoxemia has been reported in patients with Shigella and other forms of non-STEC-induced HUS $(28,90)$ and has been implicated in the pathogenesis of HUS. Endotoxemia has not been found in patients with STECassociated HUS. In contrast to Shigella, STEC are noninvasive bacteria. Indirect evidence of LPS expression in vivo has been shown by circulating antibodies against LPS in patients (91). Furthermore, compared with children with uncomplicated O157:H7 enteritis, those with HUS present an increased acute phase response to LPS, as measured by circulating LPSbinding protein (92). These findings do not, however, indicate lipid A (endotoxin) expression.

Animal models have also indicated that LPS may play a role in the pathogenesis of HUS. Rabbits injected with LPS exhibited renal cortical necrosis, resembling the renal lesions found in HUS $(93,94)$. The procoagulant events in HUS may resemble the generalized Schwartzman reaction, observed after i.v. infusion of LPS in rabbits $(93,94)$. However, the lack of disseminated intravascular coagulation and endotoxic shock in HUS indicates that these correspond to different pathophysiologic processes.

Pretreatment of rabbits and mice with Stx enhanced the lethal effects of LPS $(64,95)$. LPS hyporesponsiveness was associated with a biphasic course of disease in mice inoculated with wild-type E. coli $\mathrm{O} 157: \mathrm{H} 7$ (48) and a longer time to death in mice injected with Stx2 (96). These studies indicate a synergistic effect of Stx and LPS in vivo, as has also been shown in vitro using endothelial cells (68). Other reports observed that pretreatment with LPS could either increase or decrease Stx2-induced lethality, depending on the dose and timing of injection and that the effects could be modulated by TNF- $\alpha$ or IL-1 $\beta$ (97). A recent publication (98) showed that antibodies to LPS block adherence of STEC to human intestinal epithelial cells in vitro, although the biologic significance of this finding has not been evaluated in vivo.

Adhesins. Using in vitro cultures of human intestine, it has been shown that the initial binding of E. coli $\mathrm{O} 157: \mathrm{H} 7$ occurs in the follicle-associated epithelium of Peyer's patches within the small bowel (99). Colonization of the colon may occur thereafter (99). Adhesins are responsible for pathogen binding to intestinal epithelial cells and, as such, may be a critical step in the pathogenesis of hemorrhagic colitis (100). As with EPEC, EHEC strains exhibit attachment in a localized manner, termed attaching and effacing adherence (101). This form of intimate adherence involves the effacement of intestinal microvilli and accumulation of polymerized actin (102) and other cytoskeletal components at the site of bacterial attachment. It is mediated by intimin, an outer membrane protein $(103,104)$, encoded by the eae gene as well as by Esps A, B, and D, which mediate epithelial cell signal transduction $(26,105)$. All factors necessary for the formation of these lesions, including a translocated intimin receptor (tir, also termed EspE) $(106,107)$ are encoded in the locus of enterocyte effacement on the bacterial chromosome (26). A detailed review of these adherence mechanisms has been published recently (108). The expression of the type III secretion apparatus required for the development of attaching and effacing lesions is regulated by quorum sensing (109), a mechanism by which bacteria regulate their own population and that of other bacteria in their immediate surroundings. This may indicate that colonization of the intestine by $E$. coli $\mathrm{O} 157: \mathrm{H} 7$, ingested at low doses, may be induced and modulated by nonpathogenic $E$. coli in the human intestine.

60-MD plasmid, enterohemolysins, and heat-stable enterotoxin. E. coli $\mathrm{O} 157 \mathrm{H} 7$ and most other EHEC strains possess a large $60-\mathrm{MD}$ plasmid $(25,110)$. Human isolates were more often positive for eae and EHEC plasmid sequences than animal isolates, suggesting that these factors together with other bacterial factors may be required for full virulence of the strain (111). This plasmid was found to encode for an enterohemolysin and some biologic activity of adherence, presumably mediated by fimbriae (112). Nonpiliated mutants could, however, also adhere, and the importance of the plasmid for adherence is not clear (113). Recently, an extracellular serine protease EspP, encoded by the 60-MD plasmid, was found capable of cleaving pepsin $\mathrm{A}$ and human coagulation factor $\mathrm{V}$ (24). Although the presence of the plasmid has been associated with clinical disease, the precise pathogenic role, if any, of the enterohemolysins and the large plasmid have not been elucidated. All strains of E. coli $\mathrm{O} 157: \mathrm{H} 7$ and many other STEC possess the ast $A$ gene encoding for the heat-stable enterotoxin EAST-1 (27). Its role also remains unknown.

\section{HOST RESPONSE}

Extensive tissue injury occurs during hemorrhagic colitis and HUS, thereby generating an inflammatory response through leukocyte activation and cytokine production.

Polymorphonuclear and mononuclear cells. Several observations suggest that neutrophils and macrophages may play a key role in the pathogenesis of disease. HUS is frequently associated with circulating leukocytosis (114-125). Furthermore, this has been shown to be an independent risk factor for developing HUS $(114,116,117)$. Increased circulating neutrophil $(119,120)$ and macrophage $(120)$ counts are associated with the severity of renal failure during HUS. An increased 
number of neutrophils and macrophages have been found within the glomeruli of children with HUS, compared with controls $(7,8)$. Increased elastase levels are found in the blood of HUS patients $(121,124,125)$, indicating neutrophil activation. Circulating polymorphonuclear leukocytes are activated (121-123). Although the underlying mechanisms leading to circulating leukocytosis remain unclear, increased circulating levels of granulocyte colony-stimulating factor (126) and IL-8 (124) have been reported in children with HUS. Moreover, IL-8 levels correlated with the white blood cell count (124). Neutrophils from patients with HUS have a higher capacity to adhere to cultured human endothelium and to induce endothelial injury by degradation of endothelial fibronectin (122). The latter may be blocked by anti-CD18 MAb (122).

Mice injected with Stx developed elevated neutrophil counts. These neutrophils exhibited enhanced adhesive and cytotoxic properties, and pretreatment of mice with LPS potentiated this effect (127). In vitro, Stx1 increases the number of leukocytes adhering to endothelial cells, an effect that may be enhanced by TNF- $\alpha$ (128). Stx 1 binds to a non-Gb3 receptor on human polymorphonuclear cells (129). In the presence of human glomerular microvascular endothelial cells in vitro, Stx1 will transfer from polymorphonuclear cells to the endothelial cells. It has thus been suggested that neutrophils may transport Stx from the gut to the kidney vasculature (129). In support of this hypothesis, Stx did not induce apoptosis of neutrophils, suggesting that neutrophils are resistant to the cytotoxic effects of Stx (130).

Monocytes may play a central role in the pathogenesis of HUS, as depletion of hepatic or splenic macrophages, using clodronate, reduced Stx2 cytotoxicity in mice (131). Stx 1 binds to human monocytes via a different Gb3 subtype than on endothelial cells and leads to the secretion of TNF- $\alpha$, IL- $1 \beta$, IL-6, and IL-8 via an LPS-independent pathway (132). Other investigators also found that Stx 1 activated TNF- $\alpha$ production and gene transcription in a human monocytic cell line (133, 134). These studies show that Stx, in addition to being cytotoxic to human cells, is capable of triggering cells to produce and release cytokines.

Circulating inflammatory mediators and their role in STEC-induced disease. Various circulating inflammatory mediators, including ILs, chemokines, soluble adhesion molecules, growth factors, cytokine receptors, and acute phase response proteins, are abnormally increased in children with $\mathrm{D}^{+}$HUS $(7,92,124,126,135-148)$. Although these studies do not prove that the elevated inflammatory mediators have a role in the pathogenesis of disease, they indicate a marked host inflammatory response. In addition, elevated circulating levels of inflammatory mediators may be related to decreased renal excretion. Supporting this view, it has been reported that the half-life of IL-10 is increased in anephric mice (149). Patients with HUS have elevated circulating levels of pro- (IL-6, IL-8) and antiinflammatory (IL-10, IL-1 receptor antagonist) cytokines in comparison to patients with uncomplicated E. coli O157:H7 enteritis (135). A correlation to the severity of renal dysfunction has been made. Concentrations of IL-6, IL-8, IL-10, and the IL-1 receptor antagonist were higher during the acute phase of HUS in patients with oliguria and those requir- ing dialysis as well as in patients with lower GFR 1 year after development of HUS (136). In other studies, IL-6 concentrations correlated with anuria and extrarenal manifestations (136-138) during the acute phase of disease. Sequential samples of serum IL-6 correlated with disease activity as measured by serum creatinine, $\mathrm{Hb}$, and platelet counts, the highest levels being found during the first days after onset of anuria, normalizing at recovery (138). Evidence from clinical studies and models of renal disease indicate that IL-6 may be involved in mesangial proliferation $(150,151)$ and may thus be elevated in response to glomerular damage.

Certain mediators may be involved in chemotaxis. IL-8, a known neutrophil chemoattractant, was significantly elevated in the plasma of children with HUS and correlated to neutrophil counts (124). The highest concentrations were detected in the blood of patients who died during the acute phase of disease (124). Stx may induce IL-8 secretion from intestinal epithelial cells $(152,153)$ and thus prime the inflammatory response in the intestine, leading to increased chemotaxis and further activation of inflammatory cells. Increased serum levels of granulocyte colony-stimulating factor $(126,143)$ and monocyte chemoattractant protein-1 (7) have also been found.

TNF- $\alpha$ is a key proinflammatory cytokine that mediates inflammation and microvascular coagulation (150). Increased concentrations of TNF- $\alpha(138,140,141,143,145)$ and soluble TNF receptors (137) have been observed in HUS. There is evidence for a role of TNF- $\alpha$ in the pathogenesis of HUS. In vivo and in vitro studies have shown that Stx and TNF- $\alpha$ act in concert to induce renal cell injury. In mice Stx was found to induce TNF synthesis in kidneys and to increase the sensitivity to the toxic effects of TNF- $\alpha$ (64). Inhibition of TNF- $\alpha$ by nafamostat mesylate reduced the renal and CNS histologic changes in mice infected with E. coli O157:H7 (154). Stx infusion in baboons led to increased urinary secretion of TNF- $\alpha$ and IL-6 (65). In vitro experiments have shown that Stx1 may stimulate the production of proinflammatory cytokines within the proximal tubule, including TNF- $\alpha$, IL-1, and IL-6 (155). Preincubation of human tubular epithelial cells with TNF- $\alpha$ increased Stx-induced apoptosis (9). Stx and TNF- $\alpha$ or IL- $1 \beta$ act in synergy to induce a cytotoxic effect on endothelial cells $(67,71,73)$. Pretreatment of human saphenous vein endothelial cells with TNF- $\alpha$ before stimulation with Stx1 induced secretion of von Willebrand factor (70), which may be involved in the process of intravascular platelet aggregation. In addition, TNF- $\alpha$ increased adherence of leukocytes to Stx-stimulated endothelial cells and up-regulated adhesion proteins on the endothelial surface membrane (128), a process that could contribute to leukocyte-mediated endothelial cell damage in HUS.

In addition to elevated inflammatory mediators in the circulation, TNF- $\alpha$, IL-6, IL-8, monocyte chemotactic protein-1, basic fibroblast growth factor, and platelet activating factor have been found to be elevated in the urine of patients with $\mathrm{D}^{+}$ HUS $(7,138,140,141,156,157)$. The kinetics of the serum cytokine response differed from that in urine, and there was no correlation between serum and urine levels in the same individual, suggesting that these cytokines are produced locally within the kidney, and not filtered from the bloodstream (138, 
140). Most cytokines are peptides of low molecular weight, which are filtered from serum to urine (158). The concentration of filtered substances may be higher in urine than blood owing to reabsorption of water in the tubular epithelium. The uremic kidney with both glomerular and tubular damage would not be capable of such reabsorption. Thus we assume that the cytokines in the circulation and those in the urine are derived from different sources.

Endothelin is a vasoconstrictive peptide found to be excreted in a variety of renal diseases (159). Abnormally high levels of endothelin have been reported in the serum and urine of patients with HUS (144, 147, 160), reflecting the degree of renal injury, but possibly contributing to it by vasoactive potency.

Certain lymphokines such as IL-2, IL-4, and IL-13 were undetectable during E. coli $\mathrm{O} 157: \mathrm{H} 7$ enteritis or HUS, and low concentrations of interferon- $\gamma$ were comparable among children with hemorrhagic colitis and HUS and control subjects, suggesting that $\mathrm{T}$ lymphocytes are not activated (139). Decreased levels of soluble L-selectin were observed in children with HUS, perhaps reflecting the appearance of immature neutrophils in the circulation (135). Levels of soluble Eselectin, P-selectin, and vascular cell adhesion molecule-1 were analyzed in several studies $(135,142,146)$ and were not consistently found to be altered in comparison to controls. Finally, children with uncomplicated E. coli $\mathrm{O} 157: \mathrm{H} 7$ enteritis were found to have higher serum concentrations of transforming growth factor $\beta 1$ than those who develop HUS, possibly related to intestinal repair mechanisms (139) and gastrointestinal spillover.

\section{PROTHROMBOTIC STATE}

Thrombocytopenia is a cardinal feature of HUS. Platelets are consumed in microthrombi, and circulating platelets are degranulated (161) with an impaired aggregating ability and decreased intracellular levels of $\beta$-thromboglobulin (162). Platelet-derived microvesicles are increased, indicating their state of activation (163). HUS plasma induces aggregation of normal platelets (164), and increased platelet-derived factors such as platelet factor $4, \beta$-thromboglobulin, and P-selectin have been found $(165,166)$. Studies have attempted to identify a direct interaction between platelets and Stx. The toxin binds to the $\mathrm{Gb} 3$ receptor and to a glycolipid termed band 0.03 on platelets (167). Culture filtrates from STEC were able to induce platelet aggregation (168). Although purified Stx does not induce platelet aggregation in an aggregometer (169-171), a recent study has shown that Stx and its B subunit bind to platelets leading to direct activation. In the presence of human umbilical vein endothelial cells, pretreated with TNF- $\alpha$, Stx and the $\mathrm{B}$ subunit induce the formation of aggregates on these cells (172). Thus, platelet consumption during HUS may be related to a direct effect of Stx on platelets or may be related to Stx-induced endothelial cell injury, exposing the subendothelium. The latter may release prothrombotic substances such as von Willebrand factor and fibrinogen, thereby leading to platelet aggregation, which will in turn obscure the vessel lumen in target organs, leading to ischemic damage. Markers of endo- thelial cell activation, such as tissue plasminogen activator and plasminogen activator inhibitor 1 , are increased, indicating a prothrombotic and hypofibrinolytic state (173).

There is no consumption of coagulation factors in HUS. Prostacyclin, a potent vasodilator and inhibitor of platelet aggregation, has been found to be deficient in certain cases of HUS $(174,175)$. Deficiency may be caused by low production secondary to damaged endothelium, or by high consumption, and may promote platelet aggregation. Thromboxane is a potent vasoconstrictor that is significantly elevated during acute HUS (176).

Hemolytic anemia. Fragmentation of erythrocytes is common during the acute hemolysis seen in HUS. This may be caused by mechanical breakdown along the damaged endothelium (177). However, oxidative damage to red blood cells has also been suggested (178). Animal models have reproduced this aspect of HUS using either wild-type bacteria (48) or purified Stx (65). Using the former, endothelial cell damage could not be demonstrated, and it was therefore suggested that red blood cell fragmentation may occur independently of endothelial injury.

\section{A HYPOTHETICAL DESCRIPTION OF THE SEQUENCE OF EVENTS LEADING TO HUS}

A schematic overview of the proposed mechanisms underlying the pathogenesis of STEC-associated HUS is shown in Figure 1. STEC are ingested and establish along the intestine. The exact localization of intestinal colonization has not been defined, although recent studies using in vitro organ cultures

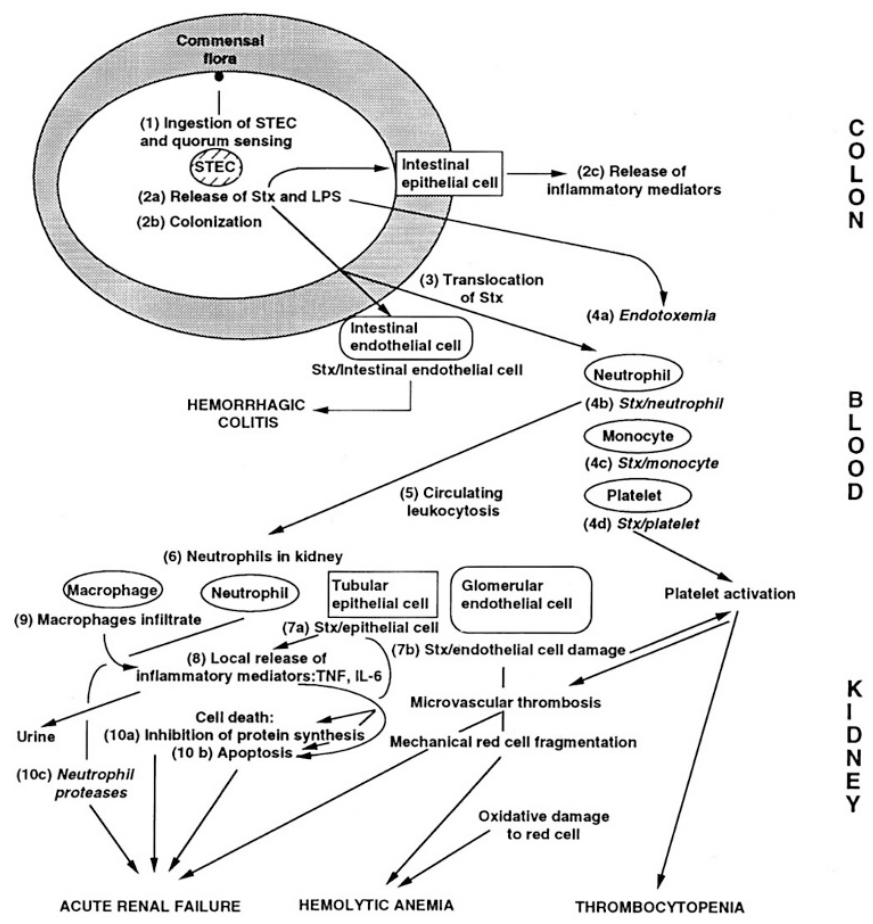

Figure 1. Overview of a hypothetical sequence of events from ingestion of STEC to the development of HUS. Numbers-1-10 give the order of events. Events which may occur simultaneously are mentioned with a small letter, e.g. $2 \mathrm{a}, 2 \mathrm{~b}$. Hypotheses for which data are either lacking or pending are shown in italics. The proposed pathophysiologic mechanisms are discussed in the text. 
suggest that EHEC initially attach to Peyer's patches, after which colonization of the colon may occur (99). Quorum sensing regulates the expression of adhesins so that even small amounts of ingested bacteria are capable of adhering (109). Adhesion occurs by the translocation of Esps from the bacterium into the host cell, leading to signal transduction and activation. Transfer of the translocated intimin receptor into the host cell enables intimate binding of intimin to the intestinal epithelium (108). Furthermore, bacteria secrete Stx, LPS, and possibly other virulence factors into the intestinal lumen and intestinal epithelial and endothelial cells $(33,39,89)$. This eventually leads to colitis with bloody diarrhea owing to cell death and intestinal vascular injury (39). Intestinal cells are activated to secrete cytokines, such as IL-8, locally and into the circulation $(124,152)$. The kinetics of the toxin-induced inflammatory response and the role of individual cytokines have yet to be determined. Stx, and possibly LPS and other virulence factors, gains access to the circulation. The mechanism by which Stx circulates and reaches its target organs has not been clarified, although binding to monocytes, polymorphonuclear cells, or platelets has been proposed $(129,132,167,172)$. On reaching the microvasculature of the kidneys (179), brain, and other $\mathrm{Gb3}$-endowed organs, the toxin binds to its receptor and induces stimulatory effects, leading to the local release of cytokines such as TNF- $\alpha$, IL-1, and IL-6 (155), and cytotoxic effects $(67-69,78)$, followed by cell death. The released cytokines lead to further influx of inflammatory cells that may also be triggered to release cytokines (132-134), and in synergy with LPS and Stx, this will increase the cytotoxic damage $(67-69,73)$. Stx is thus capable of stimulating cells to release cytokines as well as inducing cell death by inhibition of protein synthesis (32) or by apoptosis $(9,81)$. Monocytes, polymorphonuclear cells, and platelets have, however, been found to be resistant to the cytotoxic effects of Stx $(129,132,172)$. Although the cellular events that regulate Stx-triggered cell activation versus death have, as yet, not been elucidated, it has been suggested that cytotoxicity may be subsequent to binding to the $\mathrm{Gb} 3$ receptor and that binding via non-Gb3 receptors or Gb3 receptors with a different fatty acid composition will not necessarily mediate cell death $(129,132)$. Platelet consumption occurs because of direct activation by Stx and intravascular aggregation (172) or secondary to endothelial cell injury (177). Activated platelets in areas of high shear and damaged endothelium may bind to the subendothelium. Unbound platelet aggregates are removed by the reticuloendothelial cell system. Platelet consumption and removal may thus lead to thrombocytopenia. Glomerular thrombi and damage to tubular epithelial cells (6) will lower glomerular filtration and cause renal failure. Red blood cell fragmentation secondary to mechanical injury in the vasculature (177) or to oxidative damage (178) leads to hemolysis. It is notable that not every individual ingesting EHEC will exhibit symptoms. Host factors that have been proposed to contribute to HUS are young or old age (19, $180)$ and the P1 blood group (181, 182), although other, as yet unknown host factors likely also play a role.

\section{CONCLUSIONS}

This review presents advances in our current understanding of the pathogenesis of STEC-induced disease. Although the precise sequence of events leading from ingestion of bacteria to the development of HUS is still unknown, and a completely valid animal model is lacking, new data have significantly improved our knowledge and the entire E. coli $\mathrm{O} 157: \mathrm{H} 7$ genome was recently sequenced, enabling future identification of genetic sequences related to pathogenesis (183). Small quantities of bacteria may colonize the intestine by a bacterial cross-talk mechanism termed quorum sensing (109). The mechanisms of intestinal adhesion have been characterized (108). Stx is uniquely associated with bacteria that cause HUS, and together with host factors and inflammatory mediators, contributes to the target organ injury. The toxin has been found to be both stimulatory and cytotoxic and may circulate bound to polymorphonuclear cells from which it will transfer to endothelial cells (129). Stx has a cytotoxic effect on endothelial cells $(66,67)$ and has most recently been shown to activate platelets (172). These advances will hopefully enable the development of toxin binding, neutralizing, and removal therapies in the future.

\section{REFERENCES}

1. Gasser C, Gauthier E, Steck A, Siebenmann RE, Oechslin R 1955 Hamolytischuramische syndrome: bilaterale nierenrindennekrosen bei akuten erworbenen hamolytischen anamien. Schweiz Med Wochenschr 85:905-909

2. Siegler RL 1992 Central nervous system involvement in the hemolytic uremic syndrome. In: Kaplan BS, Trompeter RS, Moake JL (eds). Hemolytic Uremic Syndrome and Thrombotic Thrombocytopenic Purpura. Marcel Dekker, New York, pp 113-129

3. Rowe PC, Orrbine E, Wells GA, McLaine PN 1991 Epidemiology of hemolytic uremic syndrome in Canadian children from 1986 to 1988. J Pediatr 119:218-224

4. van de Kar NC, Roelofs HG, Muytjens HL, Tolboom JJ, Roth B, Proesmans W, Reitsma-Bierens WC, Wolff ED, Karmali MA, Chart H, Monnens LA 1996 Verocytotoxin-producing Escherichia coli infection in hemolytic uremic syndrome in part of western Europe. Eur J Pediatr 155:592-595

5. Griffin PM, Ostroff SM, Tauxe RV, Greene KD, Wells JG, Lewis JH, Blake PA 1988 Illnesses associated with Escherichia coli O157:H7 infections. Ann Intern Med 109:705-712

6. Habib R 1992 Pathology of the hemolytic uremic syndrome. In: Kaplan BS, Trompeter RS, Moake JL (eds) Hemolytic Uremic Syndrome and Thrombotic Thrombocytopenic Purpura. Marcel Dekker, New York, pp 315-353

7. Van Setten PA, Hinsbergh MV, Van Den Heuvel LPWJ, Preyers F, Dijkman HPBM, Assmann KJM, Ven Der Velden TJAM, Monnens LAH 1998 Monocyte chemoattractant protein-1 and interleukin- 8 in urine and serum of patients with hemolytic uremic syndrome. Pediatr Res 43:759-767

8. Inward CD, Howie AJ, Fitzpatrick MM, Rafaat F, Milford DV, Taylor CM 1997 Renal histopathology in fatal cases of diarrhea-associated haemolytic uraemic syndrome. Pediatr Nephrol 11:556-559

9. Karpman D, Hakansson A, Perez MT, Isakson C, Carlemalm E, Caprioli A, Svanborg C 1998 Apoptosis of renal cortical cells in the hemolytic-uremic syndrome: in vivo and in vitro studies. Infect Immun 66:636-644

10. Taguchi T, Uchida H, Kiyokawa N, Mori T, Sato N, Horie H, Takeda T, Fujimoto J 1998 Verotoxins induce apoptosis in human renal tubular epithelium derived cells. Kidney Int 53:1681-1688

11. Griffin PM, Olmstead LC, Petras RE 1990 Escherichia coli O157:H7-associated colitis. Gastroenterology 99:142-149

12. Shigematsu H, Dikman SH, Churg J, Grishman E, Duffy JL 1976 Mesangial involvement in hemolytic uremic syndrome. Am J Pathol 85:349-362

13. Argyle JC, Hogg RJ, Pysher TJ, Silva FG, Siegler RL 1990 A clinicopathological study of 24 children with hemolytic uremic syndrome: a report of the Southwest Pediatric Nephrology Study Group. Pediatr Nephrol 4:52-58

14. Asada Y, Sumiyoshi A, Hayashi T, Suzumiya J, Kaketani K 1985 Immunohistochemistry of vascular lesion in thrombotic thrombocytopenic purpura, with special reference to factor VIII related antigen. Thromb Res 38:469-479

15. Riley LW, Remis RS, Helgerson SD, McGee HB, Wells JG, Davis BR, Hebert RJ, Olcott ES, Johnson LM, Hargrett NT, Blake PA, Cohen ML 1983 Hemorrhagic colitis associated with a rare Escherichia coli serotype. N Engl J Med 308:681-685

16. O'Brien AD, Melton AR, Schmitt CK, McKee ML, Batts ML, Griffin DE 1993 Profile of Escherichia coli O157:H7 pathogen responsible for hamburger-borne outbreak of hemorrhagic colitis and hemolytic uremic syndrome in Washington. J Clin Microbiol 31:2799-2801 
17. Besser RE, Lett SM, Weber JT, Doyle MP, Barrett TJ, Wells JG, Griffin PM 1993 An outbreak of diarrhea and hemolytic uremic syndrome from Escherichia coli O157:H7 in fresh-pressed apple cider. JAMA 269:2217-2220

18. Keene WE, McAnulty JM, Hoesly FC, Williams LP, Hedberg K, Oxman GL, Barrett TJ, Pfaller MA, Fleming DW 1994 A swimming-associated outbreak of hemorrhagic colitis caused by Escherichia coli and Shigella sonnei. N Engl J Med 331:579-584

19. Carter AO, Borczyk AA, Carlson JA, Harvey B, Hockin JC, Karmali MA, Krishnan C, Korn DA, Lior H 1987 A severe outbreak of Escherichia coli O157:H7associated hemorrhagic colitis in a nursing home. N Engl J Med 316:1496-1500

20. Krishnan C, Fitzgerald VA, Dakin SJ, Behme RJ 1987 Laboratory investigation of outbreak of hemorrhagic colitis caused by Escherichia coli O157:H7. J Clin Microbiol 25:1043-1047

21. Emil S, Rockstad R, Vannix D 1998 Hemolytic uremic syndrome in a child with burn injury. J Burn Care Rehabil 19:135-137

22. Karmali MA, Petric M, Lim C, Fleming PC, Arbus GS, Lior H 1985 The association between idiopathic hemolytic uremic syndrome and infection by verotoxinproducing Escherichia coli. J Infect Dis 151:775-782

23. Schmidt H, Beutin L, Karch H 1995 Molecular analysis of the plasmid-encoded hemolysin of Escherichia coli O157:H7 strain EDL 933. Infect Immun 63:1055 1061

24. Brunder W, Schmidt H, Karch H 1997 EspP, a novel extracellular serine protease of enterohemorrhagic Escherichia coli $\mathrm{O} 157: \mathrm{H} 7$ cleaves human coagulation factor V. Mol Microbiol 24:767-778

25. Beutin L, Montengro MA, Ørskov I, Ørskov F, Prada J, Zimmermann S, Stephan R 1989 Close association of verocytotoxin (Shiga-like toxin) production with enterohemolysin production in strains of Escherichia coli. J Clin Microbiol 27:2559-2564

26. Jarvis KG, Giron JA, Jerse AE, McDaniel TK, Donnenberg MS, Kaper JB 1995 Enteropathogenic Escherichia coli contains a putative type III secretion system necessary for the export of proteins involved in attaching and effacing lesion formation. Proc Natl Acad Sci USA 92:7996-8000

27. Savarino SJ, McVeigh A, Watson J, Cravioto A, Molina J, Echeverria P, Bhan MK, Levine MM, Fasano A 1996 Enteroaggregative Escherichia coli heat-stable enterotoxin is not restricted to enteroaggregative E. coli. J Infect Dis 173:1019-1022

28. Koster F, Levin J, Walker L, Tung KSK, Gilman RH, Rahaman MM, Majid A, Islam S, Williams RC 1978 Hemolytic uremic syndrome after shigellosis: relation to endotoxemia and circulating immune complexes. N Engl J Med 298:927-933

29. Tschäpe H, Prager R, Streckel W, Fruth A, Tietze E, Böhme G 1995 Verotoxinogenic Citrobacter freundii associated with severe gastroenteritis and cases of haemolytic uraemic syndrome in a nursery school: green butter as the infection source. Epidemiol Infect 114:441-450

30. Lingwood CA, Law H, Richardson S, Petric M, Brunton JL, De Grandis S, Karmali M 1987 Glycolipid binding of purified and recombinant Escherichia coli produced verotoxin in vitro. J Biol Chem 262:8834-8839

31. Cohen A, Hannigan GE, Williams BR, Lingwood CA 1987 Roles of globotriosyland galabiosylceramide in verotoxin binding and high affinity interferon receptor. J Biol Chem 262:17088-17091

32. Obrig TG, Moran TP, Brown JE 1987 The mode of action of Shiga toxin on peptide elongation of eukaryotic protein synthesis. Biochem J 244:287-294

33. Hurley BP, Jacewicz M, Thorpe M, Lincicome LL, King AJ, Keusch GT, Acheson DWK 1999 Shiga toxins 1 and 2 translocate differently across polarized intestinal epithelial cells. Infect Immun 67:6670-6677

34. Boerlin P, McEwen SA, Boerlin-Petzold F, Wilson JB, Johnson V, Gyles CL 1999 Associations between virulence factors of Shiga toxin-producing Escherichia coli and disease in humans. J Clin Microbiol 37:497-503

35. Ostroff SM, Tarr PI, Neill MA, Lewis JH, Hargrett-Bean N, Kobayashi JM 1998 Toxin genotypes and plasmid profiles as determinants of systemic sequelae in Escherichia coli O157:H7 infections. J Infect Dis 160:994-998

36. Scotland SM, Willshaw GA, Smith HR, Rowe B 1987 Properties of strains of Escherichia coli belonging to serogroup $\mathrm{O} 157$ with special reference to production of vero cytotoxins VT1 and VT2. Epidemiol Infect 99:613-624

37. Thomas A, Chart H, Cheasty T, Smith HR, Frost JA, Rowe B 1993 Vero cytotoxinproducing Escherichia coli, particularly serogroup O157, associated with human infections in the United Kingdom: 1989-1991. Epidemiol Infect 110:591-600

38. Tesh VL, Burris JA, Owens JW, Gordon VM, Wadolkowski EA, Obrien AD, Samuel JE 1993 Comparison of the relative toxicities of Shiga-like toxins type I and type II for mice. Infect Immun 61:3392-3402

39. Jacewicz MS, Acheson DWK, Binion DG, West GA, Lincicome LL, Fiocchi C, Keusch GT 1999 Response of human intestinal microvascular endothelial cells to Shiga toxins 1 and 2 and pathogenesis of hemorrhagic colitis. Infect Immun 67:1439-1444

40. Louise CB, Obrig TG 1995 Specific interaction of Escherichia coli O157:H7 derived Shiga-like toxin II with human renal endothelial cells. J Infect Dis 172:1397-1401

41. Holloway S, Senior D, Roth L, Tisher CC 1993 Hemolytic uremic syndrome in dogs J Vet Int Med 7:220-227

42. Cowan LA, Hertzke DM, Fenwick BW, Andreasen CB 1997 Clinical and clinicopathologic abnormalities in greyhounds with cutaneous and renal glomerular vasculopathy: 18 cases (1992-1994). J Am Vet Med Assoc 210:789-793

43. Hertzke DM, Cowan LA, Schoning P, Fenwick BW 1995 Glomerular ultrastructura lesions of idiopathic cutaneous and renal glomerular vasculopathy of greyhounds. Vet Pathol 32:451-459

44. Fenwick BW, Cowan LA 1998 Canine model of haemolytic-uremic syndrome. In: Kaper JB, O'Brien AD (eds) Escherichia coli O157:H7 and Other Shiga ToxinProducing E.coli Strains. American Society for Microbiology, ASM Press, Washington DC, pp 268-277

45. Moxley RA 2000 Edema disease. Vet Clin North Am Food Anim Pract 16:175-185
46. Parreira VR, Yano T 1998 Cytotoxin produced by Escherchia coli isolated from chickens with swollen head syndrome. Vet Microbiol 62:111-119

47. Moxley RA, Francis DH 1998 Overview of animal models. In: Kaper JB, O’Brien $\mathrm{AD}$ (eds) Escherichia coli $\mathrm{O} 157: \mathrm{H} 7$ and Other Shiga Toxin-Producing E.coli Strains. American Society for Microbiology, ASM Press, Washington DC, pp $249-260$

48. Karpman D, Connell H, Svensson M, Scheutz F, Alm P, Svanborg C 1997 The role of lipopolysaccharide and Shiga-like toxin in a mouse model of Escherichia coli O157:H7 infection. J Inf Dis 175:611-620

49. Pai CH, Kelly JK, Meyers GL 1986 Experimental infection of infant rabbits with verotoxin-producing Escherichia coli. Infect Immun 51:16-23

50. Francis DH, Collins JE, Duimstra JR 1986 Infection of gnotobiotic pigs with an Escherichia coli $\mathrm{O} 157: \mathrm{H} 7$ strain associated with an outbreak of hemorrhagic colitis. Infect Immun 51:953-956

51. Tzipori S, Chow CW, Powell HR 1988 Cerebral infection with Escherichia coli O157:H7 in humans and gnotobiotic piglets. J Clin Pathol 41:1099-1103

52. Fujii J, Kita T, Yoshida S, Takeda T, Kobayashi H, Tanaka N, Ohsato K, Mizuguchi Y 1994 Direct evidence of neuron impairment by oral infection with verotoxinproducing Escherichia coli $\mathrm{O} 157: \mathrm{H}-$ in mitomycin treated mice. Infect Immun 62:3447-3453

53. Wadolkowski EA, Burris JA, O'Brien AD 1990 Mouse model for colonization an disease caused by enterohemorrhagic Escherichia coli O157:H7. Infect Immun 58:2439-2445

54. Wadolkowski EA, Sung LM, Burris JA, Samuel JE, O’Brien AD 1990 Acute rena tubular necrosis and death of mice orally infected with Escherichia coli strains that produce Shiga-like toxin type II. Infect Immun 58:3959-3965

55. Chae C, Moxley RA, Christopher-Hennings J, Francis DH, Wannemuehler MJ 1994 Shiga-like toxin-II-producing Escherichia coli O157:H7 infection in gnotobiotic piglets: protection against brain vascular lesions with SLT-II antiserum. In: Karmal MA, Goglio AG (eds) Recent Advances in Verocytotoxin Producing Escherichia coli Infections. Elsevier Science, Amsterdam, pp 241-244

56. Lindgren SW, Melton AR, O'Brien AD 1993 Virulence of enterohemorrhagic Escherichiacoli O91:H21 clinical isolates in an orally infected mouse model. Infect Immun 61:3832-3842

57. Fontaine A, Arondel J, Sansonetti PJ 1988 Role of Shiga toxin in the pathogenesis of bacillary dysentery, studied by using a Tox - mutant of Shigella dysenteriae 1 . Infect Immun 56:3099-3109

58. Zoja C, Corna D, Farina C, Sacchi G, Lingwood C, Doyle MP, Padhye VV, Abbate M, Remuzzi G 1992 Verotoxin glycolipid receptors determine the localization of microangiopathic process in rabbits given verotoxin-1. J Lab Clin Med 120:229-238

59. Lingwood CA 1994 Verotoxin binding in human renal sections. Nephron 66:21-28

60. Boyd B, Lingwood C 1989 Verotoxin receptor glycolipid in human renal tissue Nephron 51:207-210

61. Ren J, Utsunomiya I, Tagushi K, Ariga T, Tai T, Ihara Y, Miyatake T 1999 Localization of verotoxin receptors in nervous system. Brain Res 825:183-188

62. Richardson SE, Rotman TA, Jay V, Smith CR, Becker LE, Petric M, Olivieri NF, Karmali MA 1992 Experimental verocytotoxemia in rabbits. Infect Immun $60: 4154-4167$

63. Keenan KP, Sharpnack DD, Collins H, Formal SB, O'Brien AD 1986 Morphologic evaluation of the effects of Shiga toxin and Escherichia coli Shiga-like toxin on the rabbit intestine. Am J Pathol 125:69-80

64. Harel Y, Silva M, Giroir B, Weinberg A, Cleary TB, Beutler B 1993 A reporter transgene indicates renal-specific induction of tumor necrosis factor by Shiga-like toxin. J Clin Invest 92:2110-2116

65. Taylor FB, Tesh VL, DeBault L, Li A, Chang ACK, Kosanke SD, Pysher TJ, Siegler RL 1999 Characterization of the baboon responses to Shiga-like toxin. Am J Pathol 154:1285-1298

66. Obrig TG, Del Vecchio PJ, Brown JE, Moran TP, Rowland BM, Judge TK Rothman SW 1988 Direct cytotoxic action of Shiga toxin on human vascular endothelial cells. Infect Immun 56:2373-2378

67. Louise CB, Obrig TG 1991 Shiga toxin-associated hemolytic-uremic syndrome: combined cytotoxic effects of Shiga toxin, interleukin-1B, and tumor necrosis factor alpha on human vascular endothelial cells in vitro. Infect Immun 59:4173-4179

68. Louise CB, Obrig TG 1992 Shiga toxin-associated hemolytic uremic syndrome: combined cytotoxic effects of Shiga toxin and lipopolysaccharide (endotoxin) on human vascular endothelial cells in vitro. Infect Immun 60:1536-1543

69. Tesh VL, Samuel JE, Perera LP, Sharefkin JB, O'Brien AD 1991 Evaluation of the role of Shiga and Shiga-like toxins in mediating direct damage to human vascular endothelial cells. J Infect Dis 164:344-352

70. Keusch GT, Acheson DWK, Aaldering L, Erban J, Jacewicz MS 1996 Comparison of the effects of Shiga-like toxin I on cytokine- and butyrate-treated human umbilical and saphenous vein endothelial cells. J Infect Dis 173:1164-1170

71. Obrig TG, Louise CB, Lingwood CA, Boyd B, Barley-Maloney B, Daniel TO 1993 Endothelial heterogeneity in Shiga toxin receptors and responses. J Biol Chem 268:15484-15488

72. Yoshida T, Fukada M, Koide N, Ikeda H, Sugiyama T, Kato Y, Ishikawa N, Yokochi T 1999 Primary cultures of human endothelial cells are susceptible to low doses of Shiga toxins and undergo apoptosis. J Infect Dis 180:2048-2052

73. van de Kar NCAJ, Monnens LAH, Karmali MA, van Hinsbergh VWM 1992 Tumo necrosis factor and interleukin-1 induce expression of the verocytotoxin recepto globotriaosylceramide on human endothelial cells: implications for the pathogenesis of the hemolytic uremic syndrome. Blood 80:2755-2764

74. Kaye SA, Louise CB, Boyd B, Lingwood CA, Obrig TG 1993 Shiga toxinassociated hemolytic uremic syndrome: interleukin-1 enhancement of Shiga toxin cytotoxicity toward human vascular endothelial cells In Vitro. Infect Immun 61:3886-3891 
75. Louise CB, Kaye SA, Boyd B, Lingwood CA, Obrig TG 1995 Shiga-toxin associated hemolytic-uremic syndrome: effect of sodium butyrate on sensitivity of human umbilical vein endothelial cells to Shiga toxin. Infect Immun 63:2766-2769

76. Bitzan MA, Wang Y, Lin J, Marsden PA 1998 Verotoxin and ricin have novel effects on preproendothelin-1 expression but fail to modify nitric oxide synthase (ecNOS) expression and NO production in vascular endothelium. J Clin Invest 101:372-382

77. Yuhas Y, Kaminsky E, Mor M, Ashkenazi S 1996 Induction of nitric oxide production in mouse macrophages by Shiga toxin. J Med Microbiol 45:97-102

78. Hughes AK, Stricklett PK, Schmid D, Kohan DE 2000 Cytotoxic effect of Shiga toxin-1 on human glomerular epithelial cells. Kidney Int 57:2350-2359

79. Hughes AK, Stricklett PK, Kohan DE 1998 Cytotoxic effect of Shiga toxin-1 on human proximal tubule cells. Kidney Int 54:426-437

80. Waddell T, Cohen A, Lingwood CA 1990 Induction of verotoxin sensitivity in receptor-deficient cell lines using the receptor glycolipid globotriaosylceramide. Proc Natl Acad Sci USA 87:7898-7901

81. Kiyokawa N, Taguchi T, Mori T, Uchida H, Sato N, Takeda T, Fujimoto J 1998 Induction of apoptosis in normal human renal tubular epithelial cells by Escherichia coli Shiga toxins 1 and 2. J Infect Dis 178:178-184

82. Mangeney M, Lingwood CA, Taga S, Caillou B, Tursz T, Wiels J 1993 Apoptosis induced in Burkitt's lymphoma cells via Gb3/CD77, a glycolipid antigen. Cancer Res 53:5314-5319

83. Jones NL, Islur A, Haq R, Mascarenhas M, Karmali MA, Perdue MH, Zanke BW, Sherman PM 2000 Escherichia coli Shiga toxins induce apoptosis in epithelial cells that is regulated by the Bcl-2 family. Am J Physiol 278:G811-G819

84. Uchida H, Kiyokawa N, Taguchi T, Horie H, Fujimoto J, Takeda T 1999 Shiga toxins induce apoptosis in pulmonary epithelium-derived cells. J Infect Dis 180:1902-1911

85. Inward CD, Williams J, Chant I, Crocker J, Milford DV, Rose PE, Taylor CM 1995 Verocytotoxin-1 induces apoptosis in vero cells. J Infect 30:213-218

86. Lieberthal W, Levine JS 1996 Mechanisms of apoptosis and its potential role in renal tubular epithelial cell injury. Am J Physiol 271 F477-F488

87. Savill J, Mooney A, Hughes J 1996 Apoptosis and renal scarring. Kidney Int Suppl 54:S14-S17

88. Sugiyama H, Kashihara N, Makino H, Yamasaki Y, Ota Z 1996 Apoptosis in glomerular sclerosis. Kidney Int 49:103-111

89. Philpott DJ, Ackerley CA, Kiliaan AJ, Karmali MA, Perdue MH, Sherman PM 1997 Translocation of verotoxin 1 across T84 monolayers: mechanisms of bacterial toxin penetration of epithelium. Am J Physiol 273:G1349-G1358

90. Coratelli P, Buongiorno E, Passavanti G 1988 Endotoxemia in hemolytic uremic syndrome. Nephron 50:365-367

91. Bitzan M, Moebius E, Ludwig K, Mueller-Wiefel DE, Heesemann J, Karch H 1991 High incidence of serum antibodies to Escherichia coli O157 lipopolysaccharide in children with hemolytic uremic syndrome. J Pediatr 119:380-385

92. Proulx F, Seidman E, Mariscalco MM, Lee K, Caroll SF 1999 Increased circulating levels of lipopolysaccharide binding protein in children with Escherichia coli O157:H7 hemorrhagic colitis and hemolytic uremic syndrome. Clin Diagn Lab Immunol 6:773

93. Bertani T, Abbate M, Zoja C, Corna D, Remuzzi G 1989 Sequence of glomerular changes in experimental endotoxemia: a possible model of hemolytic uremic syndrome. Nephron 53:330-337

94. Butler T, Rahman H, Al-Mahmud KA, Islam M, Bardhan P, Kabir I, Rahman MM 1985 An animal model of haemolytic-uraemic syndrome in shigellosis: lipopolysaccharides of Shigella dysenteriae I and S. flexneri produce leukocyte-mediated renal cortical necrosis in rabbits. Br J Exp Pathol 66:7-15

95. Barrett TJ, Potter ME, Wachsmuth IK 1989 Bacterial endotoxin both enhances and inhibits the toxicity of Shiga-like toxin II in rabbits and mice. Infect Immun 57:3434-3437

96. Barrett TJ, Potter ME, Strockbine NA 1990 Evidence for participation of the macrophage in Shiga-like toxin II induced lethality in mice. Microbiol Pathog 9:95-103

97. Palermo M, Alves-Rosa F, Rubel C, Fernandez GC, Fernadez-Alonso G, Alberto F, Rivas M, Isturiz M 2000 Pretreatment of mice with lipopolysaccharide (LPS) o IL-1B exerts dose-dependent opposite effects on Shiga toxin-2 lethality. Clin Exp Immunol 119:77-83

98. Paton AW, Voss E, Manning PA, Paton JC 1998 Antibodies to lipopolysaccharide block adherence of Shiga toxin-producing Escherichia coli to human intestina epithelial cells. Microb Pathog 24:57-63

99. Phillips AD, Navabpour S, Hicks S, Dougan G, Wallis T, Frankel G 2000 Enterohemorrhagic Escherichia coli O157:H7 target Peyers patches in humans and cause attaching/effacing lesions in both human and bovine intestine. Gut 47:377-381

100. Dytoc M, Soni R, Cockerill F, De Azavedo J, Louie M, Brunton J, Sherman P 1993 Multiple determinants of verotoxin-producing Escherichia coli $\mathrm{O} 157: \mathrm{H} 7$ attachment-effacement. Infect Immun 61:3382-3391

101. Moon HW, Whipp SC, Argenzio RA, Levine MM, Gianella RA 1983 Attaching and effacing activities of rabbit and human enteropathogenic Escherichia coli in pig and rabbit intestines. Infect Immun 41:1340-1351

102. Knutton S, Baldwin T, Williams PH, McNeish AS 1989 Actin accumulation at sites of bacterial adhesion to tissue culture cells: basis of a new diagnostic test for enteropathogenic and enterohemorrhagic Escherichia coli. Infect Immun 57:12901298

103. Jerse AE, Yu J, Tall BD, Kaper JB 1990 A genetic locus of enteropathogenic Escherichia coli necessary for the production of attaching and effacing lesions on tissue culture cells. Proc Natl Acad Sci USA 87:7837-7843

104. Jerse AE, Kaper JB 1991 The eae gene of enteropathogenic Escherichia coli encodes a 94-kilodalton membrane protein, the expression of which is influenced by the EAF plasmid. Infect Immun 59:4302-4309
105. Jarvis KG, Kaper JB 1996 Secretion of extracellular proteins by enterohemorrhagic Escherichia coli via a putative type III secretion system. Infect Immun 64:48264829

106. Kenny B, DeVinney R, Stein M, Reinsceid DJ, Frey EA, Finlay BB 1997 Enteropathogenic $E$. coli transfers its receptor for intimate adherence into mammalian cells. Cell 91:511-520

107. Deibel C, Kramer S, Chakraborty T, Ebel F 1998 EspE, a novel secreted protein of attaching and effacing bacteria, is directly translocated into infected host cells, where it appears as a tyrosine-phosphorylated $90 \mathrm{kDa}$ protein. Mol Microbiol 28:463-474

108. Frankel G, Phillips AD, Rosenshine I, Dougan G, Kaper JB, Knutton S 1998 Enteropathogenic and enterohemorrhagic Escherichia coli: more subversive elements. Mol Microbiol 30:911-921

109. Sperandio V, Mellies JL, Nguyen W, Shin S, Kaper JB 1999 Quorum sensing controls expression of the type III secretion gene transcription and protein secretion in enterohemorrhagic and enteropathogenic Escherichia coli. Proc Natl Acad Sci USA 96:15196-15201

110. Levine MM, Xu J, Kaper JB, Lior H, Prado V, Tall B, Nataro J, Karch H, Wachsmuth K 1987 A DNA probe to identify enterohemorrhagic Escherichia coli of O157:H7 and other serotypes that cause hemorrhagic colitis and hemolytic uremic syndrome. J Infect Dis 156:175-182

111. Barrett TJ, Kaper JB, Jerse AE, Wachsmuth IK 1992 Virulence factors in Shiga-like toxin-producing Escherichia coli isolated from humans and cattle. J Infect Dis 165:979-980

112. Karch H, Heesemann J, Laufs R, O’Brien AD, Tacket CO, Levine MM 1987 A plasmid of enterohemorrhagic Escherichia coli $\mathrm{O} 157: \mathrm{H} 7$ is required for expression of a new fimbrial antigen and for adhesion to epithelial cells. Infect Immun 55:455-461

113. Toth I, Cohen ML, Rumschlag HS, Riley LW, White EH, Carr JH, Bond WW, Wachsmuth IK 1990 Influence of the 60-megadalton plasmid on adherence of Escherichia coli $\mathrm{O} 157: \mathrm{H} 7$ and genetic derivatives. Infect Immun 58:1223-1231

114. Buteau C, Proulx F, Chaibou M, Raymond D, Clermont MJ, Mariscalco MM, Lebel MH, Seidman E 2000 Leukocytosis in children with Escherichia coli O157:H7 enteritis developing the hemolytic uremic syndrome. Pediatr Infect Dis J 19:642647

115. Salzman MB, Ettenger RB, Cherry JD 1991 Leukocytosis in hemolytic uremic syndrome. Pediatr Infect Dis J 10:470-471

116. Bell P, Griffin PM, Lozano P, Christie DL, Kobayashi JM, Tarr PI 1997 Predictor of hemolytic uremic syndrome in children during a large outbreak of Escherichia coli O157:H7 infections. Pediatrics 100:127 (http://www.pediatrics.org/e12)

117. Wong CS, Jelacic S, Habeeb RL, Watkins S, Tarr PI 2000 The risk of the hemolytic uremic syndrome after antibiotic treatment of Escherichia coli O157:H7 infections. N Engl J Med 26:1930-1936

118. Martin DL, MacDonald KL, White KE, Soler JT, Osterholm MT 1990 The epidemiology and clinical aspects of the hemolytic uremic syndrome in Minnesota. N Engl J Med 323:1161-1167

119. Walters MD, Matthei IE, Kay R, Dillon MJ, Barratt TM 1989 The polymorphonuclear leukocyte count in childhood haemolytic uraemic syndrome. Pediatr Nephrol $3: 130-134$

120. Coad NA, Marshall T, Rowe B, Taylor CM 1991 Changes in the postenteropathic form of the hemolytic uremic syndrome in children. Clin Nephrol 35:10-16

121. Milford D, Taylor CM, Rafaat F, Halloran H, Dawes J 1989 Neutrophil elastases and haemolytic uraemic syndrome. Lancet 2:1153

122. Forsyth KD, Simpson AC, Fitzpatrick MM, Barratt TM, Levinsky RJ 1989 Neutrophil-mediated endothelial injury in haemolytic uraemic syndrome. Lancet 2:411414

123. Hughes DA, Smith GC, Davidson JE, Murphy AV, Beattie TJ 1996 The neutrophil oxidative burst in diarrhea-associated haemolytic uraemic syndrome. Pediatr Nephrol 10:445-447

124. Fitzpatrick MM, Shah V, Trompeter RS, Dillon MJ, Barratt TM 1992 Interleukin- 8 and polymorphoneutrophil leucocyte activation in hemolytic uremic syndrome of childhood. Kidney Int 42:951-956

125. Fitzpatrick MM, Shah V, Filler G, Dillon MJ, Barratt TM 1992 Neutrophil activation in the haemolytic uraemic syndrome: free and complexed elastase in plasma. Pediatr Nephrol 6:50-53

126. Vierzig A, Roth B, Querfeld U, Michalk D 1998 A 12-year-old boy with fatal hemolytic uremic syndrome, excessive neutrophilia and elevated endogenous granulocyte-colony-stimulating-factor serum concentrations. Clin Nephrol 50:56-59

127. Fernandez GC, Rubel C, Dran G, Gomez S, Isturiz MA, Palermo MS 2000 Shiga toxin-2 induces neutrophilia and neutrophil activation in a murine model of hemolytic uremic syndrome. Clin Immunol 95:227-234

128. Morigi M, Micheletti G, Figliuzzi M, Imberti B, Karmali MA, Remuzzi A, Remuzzi G, Zoja C 1995 Verotoxin-1 promotes leukocyte adhesion to cultured endothelial cells under physiologic flow conditions. Blood 86:4553-4558

129. Te Loo, Monnens LA, van Der Velden TJ, Vermeer MA, Preyers F, Demacker PN, van Den Heuvel LP, van Hinsbergh VW 2000 Binding and transfer of verocytotoxin by polymorphonuclear leukocytes in hemolytic uremic syndrome. Blood 95:33963402

130. King AJ, Sundaram S, Cendoroglo M, Acheson DW, Keusch GT 1999 Shiga toxin induces superoxide production in polymorphonuclear cells with subsequent impairment of phagocytosis and responsiveness to phorbol esters. J Infect Dis 179:503-507

131. Palermo MS, Alver Rosa MF, Van Rooijen N, Isturiz MA 1999 Depletion of liver and splenic macrophages reduces the lethality of Shiga toxin- 2 in a mouse model. Clin Exp Immunol 116:462-467

132. Van Setten PA, Monnens LA, Verstraten RG, van den Heuvel LP, van Hinsbergh VW 1996 Effects of verocytotoxin-1 on nonadherent human monocytes: binding 
characteristics, protein synthesis and induction of cytokine release. Blood 88:174183

133. Sakiri R, Ramegowda B, Tesh VL 1998 Shiga toxin 1 activates tumor necrosis factor-alpha gene transcription and nuclear translocation of the transcriptional activators nuclear factor-kappa B and activator protein-1. Blood 92:558-566

134. Foster GH, Armstrong CS, Sakiri R, Tesh VL 2000 Shiga toxin-induced tumor necrosis factor alpha expression: requirement for toxin enzymatic activity and monocyte protein kinase $\mathrm{C}$ and protein tyrosine kinase. Infect Immun 68:5183-5189

135. Proulx F, Litalien C, Turgeon JP, Mariscalco MM, Seidman E 1998 Inflammatory mediators in hemorrhagic colitis and hemolytic uremic syndrome. Pediatr Inf Dis 17:899-904

136. Litalien C, Proulx F, Mariscalco MM, Robitaille P, Turgeon JP, Orrbine E, Rowe PC, McLaine PN, Seidman E 2000 Circulating inflammatory cytokine levels predic severity of renal failure in hemolytic uremic syndrome. Pediatr Nephrol 35:28-34

137. Van de Kar NCAJ, Sauerwein RW, Demacker PNM, Grau GE, Van Hinsbergh VWM, Monnens LAH 1995 Plasma cytokine levels in hemolytic uremic syndrome. Nephron 71:309-313

138. Karpman D, Andreasson A, Thysell H, Kaplan BS, Svanborg C 1995 Cytokines in childhood hemolytic uremic syndrome and thrombotic thrombocytopenic purpura. Pediatr Nephrol 9:694-699

139. Proulx F, Dugas MA, Litalien C, Seidman E 2000 Circulating levels of transforming growth factor beta 1 and lymphokines in children with hemolytic uremic syndrome. Am J Kidney Dis 35:1-7

140. Yamamoto T, Isokawa S, Miyata H, Yoshioka K 1999 Evaluation of thrombomodulin and tumor necrosis factor-alpha levels in patients with hemolytic uremic syndrome caused by enterohemorrhagic Escherichia coli O157:H7 infection. Nippon Jinzo Gakkai Shi 41:60-64

141. Inward CD, Varagunam M, Adu D, Milford DV, Taylor CM 1997 Cytokines in haemolytic uraemic syndrome associated with verocytotoxin-producing Escherichia coli infection. Arch Dis Child 77:145-147

142. Inward CD, Pall AA, Adu D, Milford DV, Taylor CM 1995 Soluble circulating cel adhesion molecules in haemolytic uraemic syndrome. Pediatr Nephrol 9:574-578

143. Murata A, Shimazu T, Yamamoto T, Taenaka N, Nagayama K, Honda T, Sugimoto H, Monden M, Matsura N, Okada S 1998 Profiles of circulating inflammatory and anti-inflammatory cytokines in patients with hemolytic uremic syndrome due to $E$. coli $\mathrm{O} 157$ infection. Cytokine 10:544-548

144. Yamamoto T, Nagayama K, Satomura K, Honda T, Okada S 2000 Increased serum IL-10 and endothelin levels in hemolytic uremic syndrome caused by Escherichia coli O157. Nephron 84:326-332

145. Lopez EL, Contrini MM, Devoto S 1995 Tumor necrosis factor concentrations in hemolytic uremic syndrome patients and children with bloody diarrhea in Argentina. Pediatr Infect Dis J 14:594-598

146. Nevard CHF, Blann AD, Jurd KM, Haycock GB, Hunt B 1999 Markers of endothelial cell activation and injury in childhood haemolytic uraemic syndrome. Pediatr Nephrol 13:487-492

147. Kohan DE, Padilla EC, Sielger RL 1994 Endothelin concentration and endothelin stimulating activity in the plasma of children with post-diarrheal hemolytic uremic syndrome. In: Karmali MA, Goglio AG (eds) Recent Advances in VerocytotoxinProducing Escherichia coli Infections. Elsevier, Amsterdam, pp 377-379

148. Masri C, Proulx F, Toledano B, Clermont MJ, Mariscalco MM, Seidman E, Carcillo J 2000 Soluble Fas and soluble Fas-L in children with Escherichia coli $\mathrm{O} 157: \mathrm{H} 7$ infections. Am J Kidney Dis 36:687-694

149. Chiu PJS, Radwanski E, Tetiloff G, Monge A, Swanson SJ 1996 Interleukin-10 pharmacokinetics in intact and nephrectomized mice. Eur Cytokine Netw 7:67-69

150. Akira S, Hirano T, Taga T, Kishimoto T 1990 Biology of multifunctional cytokines IL-6 and related molecules: IL-1, TNF. FASEB J 4:2860-2867

151. Ohta K, Takano N, Seno A, Yachie A, Miyawaki T, Yokoyama H, Tomosugi N, Kato E, Taniguchi N 1992 Detection and clinical usefulness of urinary interleukin-6 in the diseases of the kidney and the urinary tract. Clin Nephrol 38:185-189

152. Thorpe CM, Hurley BP, Lincicome LL, Jacewicz MS, Keusch GT, Acheson DW 1999 Shiga toxins stimulate secretion of interleukin- 8 from intestinal epithelial cells. Infect Immun 67:5985-5993

153. Yamasaki C, Natori Y, Zeng XT, Ohmura M, Yamasaki S, Takeda Y, Natori Y 1999 Induction of cytokines in a human colon epithelial cell line by Shiga toxin 1 and 2 but not by non-toxic mutant Stx 1 which lacks $N$-glycosidase activity. FEBS Let 442:231-234

154. Isogai E, Isogai H, Kimura K, Hayashi S, Kubota T, Fujii N, Takeshi K 1998 Role of tumor necrosis factor alpha in gnotobiotic mice infected with Escherichia coli O157:H7 strain. Infect Immun 66:197-202

155. Hughes AK, Stricklett PK, Kohan DE 1998 Shiga toxin-1 regulation of cytokine production by human proximal tubule cells. Kidney Int 54:1093-1106

156. Ray PE, Liu XH, Xu L, Rakusan T 1999 Basic fibroblast growth factor in HIV-associated hemolytic uremic syndrome. Pediatr Nephrol 13:586-593

157. Benigni A, Boccardo P, Noris M, Remuzzi G, Siegler RL 1992 Urinary excretion of platelet-activating factor in haemolytic uraemic syndrome. Lancet 339:835-836

158. Katz AI, Emmanouel DS 1978 Metabolism of polypeptide hormones by the normal kidney and in uremia. Nephron 22:69-80
159. Mattyus I, Zimmerhack1 LB, Schwartz A, Brabdis M, Milteyi M, Tulassay T 1997 Renal excretion of endothelin in children. Pediatr Nephrol 11:513-521

160. Siegler RL, Edwin SS, Christofferson RD, Mitchell MD 1991 Endothelin in the urine of children with the hemolytic uremic syndrome. Pediatrics 88:1063-1066

161. Fong JS, Kaplan BS 1982 Impairment of platelet aggregation in hemolytic uremic syndrome. Blood 60:564-570

162. Sassetti B, Vizcargüénaga MI, Zanaro NL, Silva MV, Kordich L, Florentini L, Diaz M, Vitacco M, Sanchez Avalos JC 1999 Hemolytic uremic syndrome in children platelet aggregation and membrane glycoproteins. J Pediatr Hematol Oncol 21:123128

163. Galli M, Grassi A, Barbui T 1996 Platelet-derived microvesicles in thrombotic thrombocytopenic purpura and hemolytic uremic syndrome. Thromb Haemost $75: 427-431$

164. Walters MD, Levin M, Smith C, Nokes TJ, Hardisty RM, Dillon MJ, Barratt TM 1988 Intravascular platelet activation in the hemolytic uremic syndrome. Kidney Int $33: 107-115$

165. Appiani AC, Edefonti A, Bettinelli A, Cossu MM, Paracchini ML, Rossi E 1982 The relationship between plasma levels of the factor VIII complex and platelet release products B-thromboglobulin and platelet factor 4 in children with the haemolytic uraemic syndrome. Clin Nephrol 17:195-199

166. Katayama M, Handa M, Araki Y, Ambo H, Kawai Y, Watanabe K, Ikeda Y 1993 Soluble P-selectin is present in normal circulation and its plasma level is elevated in patients with thrombotic thrombocytopenic purpura and haemolytic uraemic syndrome. Br J Haematol 84:702-710

167. Cooling LLW, Walker KE, Gille T, Koerner TAW 1998 Shiga toxin binds human platelets via globotriaosylceramide $\left(\mathrm{P}^{\mathrm{k}}\right.$ antigen) and a novel platelet glycosphingolipid. Infect Immun 66:4355-4366

168. Rose PE, Armour JA, Williams CE, Hill F 1985 Verotoxin and neuraminidase induced platelet aggregating activity in plasma: their possible role in the pathogenesis of the haemolytic uraemic syndrome. J Clin Pathol 38:438-441

169. Yoshimura K, Fujii J, Yutsudo T, Kikuchi R, Soejima T, Shirahata S, Yoshida S 1998 No direct effects of Shiga toxin 1 and 2 on the aggregation of human platelets in vitro. Thromb Haemost 80:529-530

170. Thorpe CM, Flaumenhaft R, Hurley B, Jacewicz M, Acheson DWK, Keusch GT 1999 Shiga toxins do not directly stimulate alpha-granule secretion or enhance aggregation of human platelets. Acta Haematol 102:51-55

171. Viisoreanu D, Polanowska-Grabowska R, Suttitanamongkol S, Obrig TG, Gear AR 2000 Human platelet aggregation is not altered by Shiga toxin 1 or 2 . Thromb Res 98:403-410

172. Karpman D, Papadopoulou D, Nilsson K, Sjögren A-C, Mikaelsson C, Lethagen S 2001 Platelet activation by Shiga toxin and circulatory factors as a pathogenetic mechanism in the hemolytic uremic syndrome. Blood 97:3100-3108

173. van de Kar NC, van Hinsbergh VW, Brommer EJ, Monnens LA 1994 The fibrinolytic system in the hemolytic uremic syndrome: in vivo and in vitro studies. Pediatr Res 36:257-264

174. Remuzzi G, Misiani R, Marchesi D, Livio M, Mecca G, de Gaetano G, Donati MB 1978 Haemolytic-uraemic syndrome: deficiency of plasma factor(s) regulating prostacyclin activity? Lancet 2:871-872

175. Alam AN, Abdal NM, Wahed MA, Rao B, Kawser CA, Hoque M, Rahaman MM 1991 Prostacyclin concentrations in haemolytic uraemic syndrome after acute shigellosis in children. Arch Dis Child 66:1231-1234

176. Tonshoff B, Momper R, Kuhl PG, Schweer H, Scharer K, Seyberth HW 1990 Increased thromboxane biosynthesis in childhood hemolytic uremic syndrome. Kidney Int 37:1134-1141

177. Zoja C, Remuzzi G 1992 The pivotal role of the endothelial cell in the pathogenesis of HUS. In: Kaplan BS, Trompeter RS, Moake JL (eds) Hemolytic Uremic Syndrome and Thrombotic Thrombocytopenic Purpura. Marcel Dekker, New York, pp $389-404$

178. Turi S, Nemeth I, Vargha I, Matkovics B 1994 Oxidative damage of red blood cells in haemolytic uraemic syndrome. Pediatr Nephrol 8:26-29

179. Uchida H, Kiyokawa N, Horie H, Fujimoto J, Takeda T 1999 The detection of Shiga toxins in the kidney of a patient with hemolytic uremic syndrome. Pediatr Res 45:133-137

180. Ostroff SM, Kobayashi JM, Lewis JH 1989 Infections with Escherichia coli O157:H7 in Washington State: the first year of statewide disease surveillance. JAMA 262:355-359

181. Newburg DS, Chaturvedi P, Lopez EL, Devoto S, Fayad A, Cleary TG 1993 Susceptibility to haemolytic-uraemic syndrome relates to erythrocyte glycosphingolipid patterns. J Infect Dis 168:476-479

182. Taylor CM, Milford DV, Rose PE, Roy TCF, Rowe B 1990 The expression of blood group P1 in post-enteropathic haemolytic uraemic syndrome. Pediatr Nephrol 4:59-61

183. Perna NT, Plunkett G, Burland V, Mau B, Glasner JD, Rose DJ, Mayhew GF, Evans PS, Gregor J, Kirkpatrick HA, Posfai G, Hackett J, Klink S, Boutin A, Shao Y, Miller L, Grotbeck EJ, Davis NW, Lim A, Dimalanta ET, Potamousis KD, Apodaca J, Anantharam TS, Lin J, Yen G, Schwartz DC, Welch RA, Blattner FR 2001 Genome sequence of enterohemorrhagic Escherichia coli O157:H7. Nature 409:529-533 